by two round constrictions, each having a bore of 3.2 sq. $\mathrm{mm}$. and a length of $3 \mathrm{~mm}$.; or 'by four resistances in series, each having a bore of 5 sq. mm., provided they were sufficiently widely separated.

\section{Discussion}

The experiments in vivo demonstrate that the cross-sectional area of an effective constriction is unrelated to the normal area of the artery and also that the human carotid artery must be very severely narrowed before there is any change of pressure gradient or of flow. This is to be expected from simple physiological principles; even in the cerebral circulation the major peripheral resistance lies in the smallest vessels, the large vessels contributing very little. A moderate constriction of a large artery, though it may increase large-vessel resistance many times, has disproportionately small effects on the total peripheral resistance, and a very tight constriction is necessary before large-vessel resistance approaches a significant fraction of the total resistance.

Spontaneous atherosclerotic stenosis is much more varied in shape than the standardized constrictions we have studied; their inflow and outflow tracts tend to be curved, and their lumens tend to be irregularly round or oval rather than slit-like, but the general effects of shape and length must still be valid. Allowing for these differences, we can correlate the crosssectional area of a stenosis with its possible effects on blood flow. It is very improbable that a stenosis is significant if its minimal cross-section is more than 5 sq. mm., even if it occupies the whole length of the internal carotid, and this is also true for several stenoses in series ; it is very probable that a stenosis is significant if its minimal cross-section is less than 2 sq. mm., however short it is ; between these two extremes of area stenoses may or may not be significant, depending on their shape and length, and their importance can only be determined by experiment.

These results in one carotid artery are not modified by the presence of additional stenoses in the other three extracranial arteries if none of them constitute a " critical " resistance.

It is difficult to apply these criteria to reports of the incidence of atherosclerosis in cadavers which use the W.H.O. classification in terms of the percentage reduction of the normal lumen, since we find that the bore of a "critical" constriction is unrelated to the normal lumen. The normal lumen of the common carotid artery in our experiments ranged from 17 to
55 sq. mm., with a mean of 30 sq. mm., and the stenosis which we would regard as " possibly significant" with a cross-sectional area of 2-5 sq. mm. corresponds in the W.H.O. classification to an average reduction of the lumen by $84 \%$ to $93 \%$; the internal carotid artery has a lumen somewhat less than the common carotid, but, even allowing for this, many of the stenoses classified as severe by Hutchinson and Yates (1957, 1961) and by Schwartz and Mitchell (1961) almost certainly had negligible effects on resistance.

We suggest that, in future surveys, stenotic lesions in arteries should be classified in terms of their hydraulic resistance measured in a perfusion circuit, using transmural pressures, viscosity, and flow rate corresponding to those present in vivo; where this is impossible the stenosis should be classified in terms of its absolute dimensions rather than in relation to the unstenosed region of the artery.

\section{Summary}

We have determined the dimensions of the constriction which just produces a detectable change of pressure gradient and flow in the internal carotid artery of conscious human subjects.

This " critical" constriction has been duplicated in a perfusion circuit, its hydraulic resistance measured and compared with the resistance of other constrictions of different shapes and lengths.

It is concluded that a stenosis will significantly reduce blood flow if its cross-sectional area is less than 2 sq. $\mathrm{mm}$. If the minimal area is more than 5 sq. $\mathrm{mm}$. blood flow will not be reduced, even by a long stenosis or by several stenoses in series. If the minimal lesion is between 2 and 5 sq. mm., blood flow may be reduced, depending on the shape, on the number of stenoses in series, and, to a less extent, on the length of the stenosis.

We are indebted to the surgeons at Atkinson Morley's Hospital, London, for the opportunity to study cases under their care; to the National Institutes of Health, Bethesda, U.S.A., for the cost of the apparatus ; and to the Wellcome Trust for financial support to two of us (D. J.D. and R. D. L.).

\section{REFERENCES}

Brice, J. G., Dowsett, D. J., and Lowe, R. D. (1964). Lancet, 1, 84. Hutchinson, E. C., and Yates, P. O. (1957). Ibid., 1, 2. Schwartz, C. J., and Mitchell, J. R. A. (1961). Brit. med. F., 2, 1057 Yates, P. O., and Hutchinson, E. C. (1961). Spec. Rep. Ser. med. Res. Coun. (Lond.), No. 300.

\title{
Formimino-glutamic Acid Excretion in Anaemia of Pregnancy
}

\author{
MORAG CHISHOLM,* M.B., CH.B.; A. A. SHARP,* M.A., M.D., B.SC., M.C.PATH.
}

When anaemia develops during pregnancy it is usually due to iron deficiency (Fisher and Biggs, 1955), though physiological anaemia due to hydraemia may play a minor part (Lawrence, 1962). Megaloblastic anaemia responding to folic acid can occur in some patients, but the recognition of this condition in pregnancy may be difficult. Unless megaloblasts can be demonstrated in the peripheral blood or buffy coat, a bone-marrow biopsy is necessary before a definite diagnosis can be made. Even with the aid of bone-marrow biopsy

* Haematology Department, Radcliffe Infirmary, Oxford. it may be difficult to be certain that haematopoiesis is abnormal.

This investigation was undertaken to see if the measurement of formimino-glutamic acid (Figlu) in the urine could be used instead of bone-marrow biopsy and could provide a method of determining whether folic-acid deficiency was present in any given patient. This test has been found to be useful in detecting folic-acid deficiency in non-pregnant individuals (Kohn et al., 1961 ; Luhby et al., 1959 ; Knowles et al., 1960), but reports of its value in anaemia of pregnancy have been conflicting (Hibbard, 1962 ; Chanarin et al., 1963). 


\section{Material and Methods}

The urinary Figlu excretion has been estimated in 102 pregnant women and correlated with the haematological state, including the bone-marrow appearance, in every case, and the serum folic-acid activity (F.A.A.) and serum vitamin-B $B_{12}$ levels where available. The patients were seen in the Nuffield Department of Obstetrics between July 1961 and November 1963 and were not a random sample of pregnant women. A considerable number had been treated with oral iron for some time and were referred because of poor response; some had had no previous iron therapy. Of the 102 women, 20 had a haemoglobin concentration of $11 \mathrm{~g} . / 100 \mathrm{ml}$. or more, which we regard as being within the normal range in the later months of pregnancy. The remainder showed a varying degree of anaemia ; in 22 it was mild (10 to $10.9 \mathrm{~g} . / 100 \mathrm{ml}$.), in 23 moderate (9 to $9.9 \mathrm{~g} . /$ $100 \mathrm{ml}$.), and in 37 severe (less than $9 \mathrm{~g} . / 100 \mathrm{ml}$.).

Patients were investigated at different stages of pregnancy but the majority were in the last trimester.

Figlu Excretion.-Figlu was measured in urine collected between three and eight hours after ingestion of $15 \mathrm{~g}$. of L-histidine monohydrochloride, using the low-voltage electrophoresis method of Kohn et al. (1961). A solution of pure Figlu of known concentration was run in parallel to provide a quantitative estimation of excretion. Increased excretion was thought to be present if the amount of Figlu excreted in the urine exceeded $2 \mathrm{mg}$./hour.

Serum Folic-acid Activity.-This was measured by microbiological assay using Lactobacillus casei as test organism by Spray's (1964) modification of the method described by Waters and Mollin (1961). The normal range in healthy non-pregnant adults is from 2.1 to $28 \mathrm{~m} \mu \mathrm{g}$. $/ \mathrm{ml}$, , with an average of $7.8 \mathrm{~m} \mu \mathrm{g} . / \mathrm{ml}$. ; the lowest level is lower than that found by other techniques.

Serum Vitamin $B_{12}$. The serum vitamin- $B_{12}$ levels were estimated according to the method of Boczarow (1961) using Lactobacillus leichmanii. In our laboratory the normal range is $150-800 \mu \mu \mathrm{g} . / \mathrm{ml}$.

Bone-marrow Biopsy.-Smears from each patient were examined by two independent observers before the Figlu results were known, and erythropoiesis was classified as normoblastic, megaloblastic, or "transitional." In the absence of frank megaloblastosis transitional erythropoiesis was regarded as being present if erythroblasts with some but not all of the features of the classical megaloblast were seen. Usually multiple or frequent Howell-Jolly bodies and/or giant band cells and metamyelocytes were noted in addition. As these changes are not found in simple iron deficiency and in non-anaemic pregnant women they are thought to represent abnormal erythropoiesis.

\section{Results}

Relation of Figlu Excretion to Haemoglobin Concentration.Table I shows that the incidence of increased Figlu excretion was significantly greater in patients with a haemoglobin concentration of less than $9 \mathrm{~g} . / 100 \mathrm{ml}$. $(\mathrm{P}<0.05)$. Women who - were not anaemic were as likely to have increased excretion as those who were moderately so.

Relation of Figlu Excretion to Type of Erythropoiesis.-Figlu excretion is related to the type of erythropoiesis in Table II. Patients who excreted increased amounts of Figlu were more likely

TABLe I.-Figlu Excretion Related to Haemoglobin Concentration

\begin{tabular}{|c|c|c|c|}
\hline \multicolumn{2}{|c|}{$\begin{array}{l}\text { Haemoglobin Concentration } \\
\text { (g. } / 100 \mathrm{ml} .)\end{array}$} & \multirow{2}{*}{$\begin{array}{c}\begin{array}{c}\text { Normal } \\
\text { Figlu }\end{array} \\
25 \\
20 \\
19 \\
8 \\
9\end{array}$} & $\begin{array}{c}\text { Increased } \\
\text { Figlu }\end{array}$ \\
\hline $\begin{array}{l}<9 \text { g. }(<61 \%) \\
9-9.9 \text { g. }(61-67 \%) \\
10-10.9 \text { g. }(68-73 \%) \\
11-11.9 \text { g. }(74-81 \%) \\
12 \text { g. \& over }(>81 \%)\end{array}$ & $\begin{array}{l}\ldots \\
\cdots \\
\cdots \\
\cdots\end{array}$ & & $\begin{aligned} 12 & (32 \%) \\
3 & (13 \%) \\
3 & (14 \%) \\
2 & (20 \%) \\
1 & (10 \%)\end{aligned}$ \\
\hline
\end{tabular}

to have megaloblastic or transitional erythropoiesis $(P<0.05)$. The correlation is not a good one, however, since $43 \%$ of patients with increased excretion had normoblastic marrows and more than half of the patients with megaloblastic or transitional marrows had normal Figlu excretion.

TABLE II.-Relation of Figlu Excretion and the Bone-marrow Appearance

\begin{tabular}{ccc|c|c|c|c}
\hline \multicolumn{2}{c|}{ Figlu } & & $\begin{array}{c}\text { Megaloblastic } \\
\text { Erythropoiesis }\end{array}$ & $\begin{array}{c}\text { Transitional } \\
\text { Erythropoiesis }\end{array}$ & $\begin{array}{c}\text { Normoblastic } \\
\text { Erythropoiesis }\end{array}$ & Total \\
\hline \begin{tabular}{ccc|c} 
Normal \\
Increased
\end{tabular} & $\ldots$ & $\ldots$ & 10 & 12 & 59 & 81 \\
\hline Total &. &. & 8 & 4 & 9 & 21 \\
\hline
\end{tabular}

Relation of Figlu Excretion to Serum Folic-acid Activity.The Figlu excretion is correlated with the serum F.A.A. in 41 patients (Table III). Patients with increased Figlu excretion were more likely to have a low serum F.A.A. than those with normal excretion. Nevertheless, half of the patients with low serum F.A.A. had normal Figlu excretion. When Figlu excretion and serum F.A.A. are related to the type of erythropoiesis there is a considerable overlap (Fig. 1). However, four of the

TABLE III.-Figlu Excretion Related to Serum Folic-acid Activity

\begin{tabular}{|c|c|c|}
\hline Serum Folic-acid Activity & Normal Figlu & Increased Figlu \\
\hline $\begin{array}{l}\text { Normal }(2 \cdot 1-28 \mathrm{~m} \mu \mathrm{g} . / \mathrm{ml} .) \\
<2 \cdot 1 \mathrm{~m} \mu \mathrm{g} . / \mathrm{ml} .\end{array}$ & $\begin{array}{r}26 \\
5\end{array}$ & $\begin{array}{l}5 \\
5\end{array}$ \\
\hline
\end{tabular}

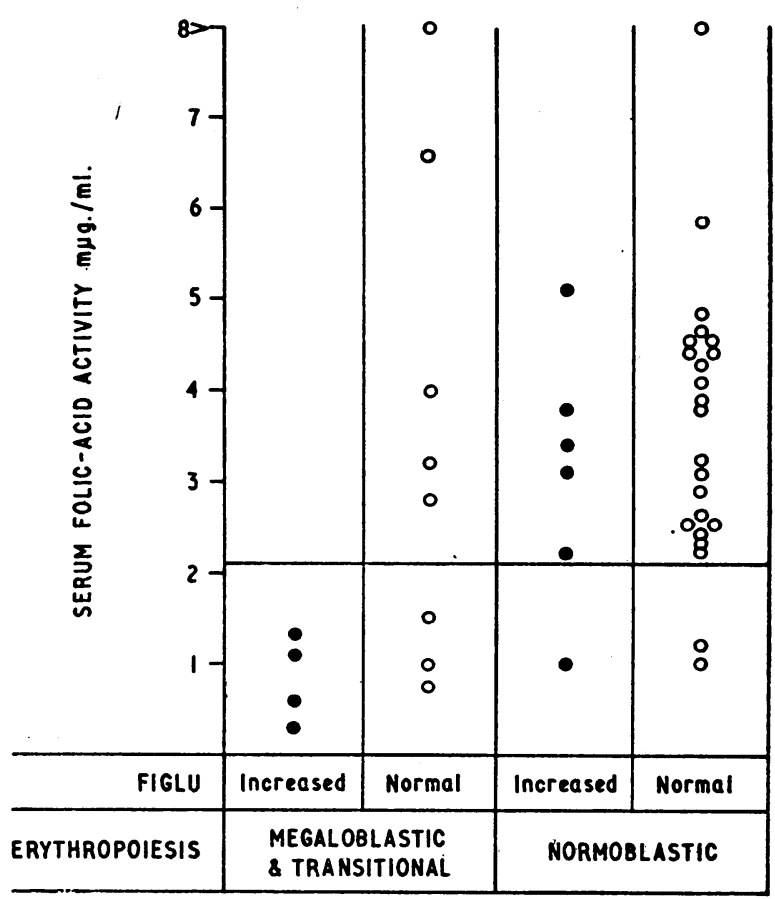

FIG. 1.-Figlu excretion related to the serum folic-acid activity and erythropoiesis.

five patients with increased Figlu excretion and a low serum F.A.A. had megaloblastic or transitional erythropoiesis.

Relation of Figlu Excretion to Serum Vitamin-B ${ }_{12}$ Levels.Serum vitamin-B $B_{12}$ levels were estimated in 69 women and the results correlated with Figlu excretion (Table IV). Patients with normal Figlu excretion had a greater chance of having a low serum vitamin- $B_{12}$ level than those with increased excretion irrespective of the type of erythropoiesis. The association of normal Figlu excretion with low vitamin- $B_{12}$ levels is statistically significant only when erythropoiesis is megaloblastic or transitional (Table V ; Fig. 2). Furthermore, it shows that megaloblastic or transitional erythropoiesis was found as often in association with an abnormally low serum vitamin- $B_{12}$ level as with an increase in Figlu excretion. 
Relation of Figlu Excretion to Both Serum F.A.A. and Serum Vitamin- $B_{12}$ Levels.-Fig. 3 shows that there was no clear-cut relation between serum F.A.A. and vitamin-B $B_{12}$ levels, but does again demonstrate the absence of increased Figlu excretion when

TABLE IV.-Relation of Figlu Excretion to the Serum Vitamin $B_{12}$

\begin{tabular}{c|c|c|c|c}
\hline Serum Vitamin $B_{12}$ & $\begin{array}{c}\text { Normal } \\
\text { Figlu }\end{array}$ & $\begin{array}{c}\text { Increased } \\
\text { Figlu }\end{array}$ & Total & Significance of Difference \\
\hline $\begin{array}{c}\text { Normal (150- } \\
800 \mu \mu . / \mathrm{ml} .) \\
\operatorname{Low}(<150 \mu \mu \mathrm{g} . / \mathrm{mi} .)\end{array}$ & $\begin{array}{c}31 \\
19\end{array}$ & $\begin{array}{c}17 \\
2\end{array}$ & $\begin{array}{c}48 \\
21\end{array}$ & $\begin{array}{l}\chi^{2}=4.9085 . * \mathrm{n}=1 . \\
\mathrm{P}<0 \cdot 05 . \text { Significant }\end{array}$ \\
\hline
\end{tabular}

With Yates's correction.

TABLE V.-Relation of Figlu Excretion, Serum Vitamin-B $B_{12}$ Levels, and Erylhropoiesis

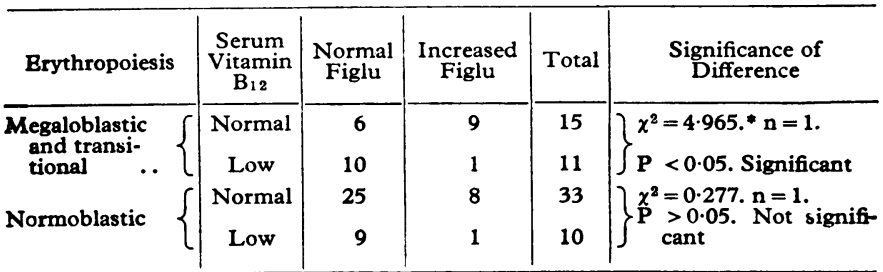

- With Yates's correction.

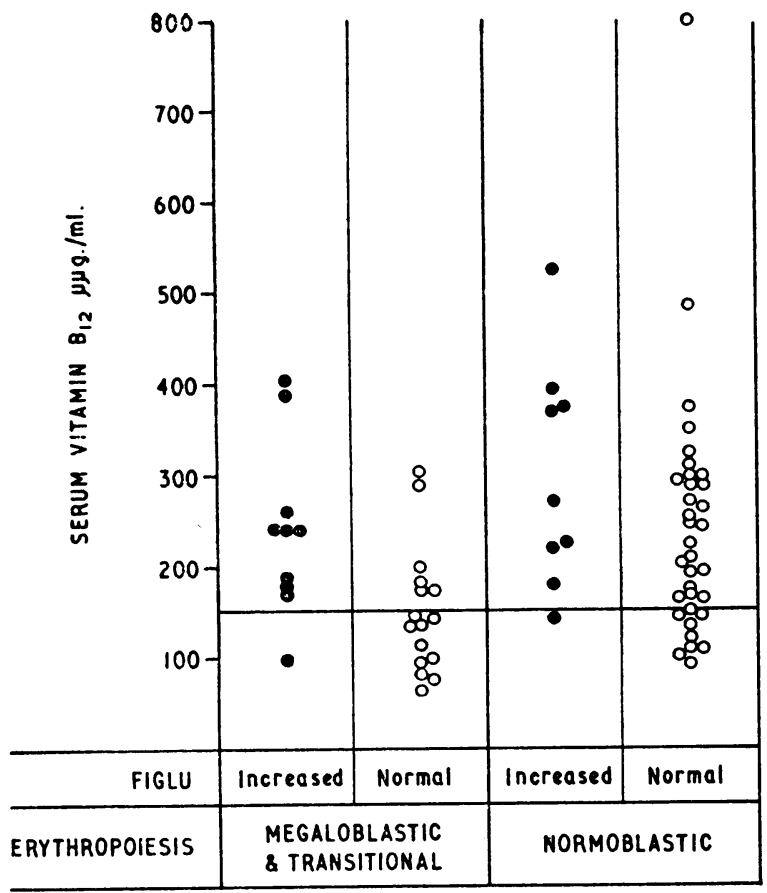

Fig. 2.-Figlu excretion related to serum vitamin $B_{12}$ and erythropoiesis.

the serum vitamin $B_{12}$ was low. The small number of patients with megaloblastic or transitional erythropoiesis and increased Figlu excretion all had a low serum F.A.A. and a normal serum vitamin $B_{12}$. Only one out of the eight who had similar erythropoiesis and a normal Figlu excretion had a low serum F.A.A. and normal serum vitamin $\mathbf{B}_{12}$.

Relation of Figlu Excretion to Iron Deficiency.-There was no correlation between Figlu excretion and iron deficiency. In the 68 patients with normoblastic erythropoiesis evidence of iron deficiency was found in 40 ; six of these had increased excretion, compared with 3 of the 28 patients in whom there was no evidence of iron deficiency.

\section{Discussion}

The results demonstrate that the measurement of Figlu excretion after histidine-loading is no substitute for bonemarrow biopsy in detecting megaloblastic or transitional erythropoiesis during pregnancy. Although patients with increased excretion are more likely to have megaloblastic or transitional erythropoiesis than those in whom the excretion is normal, a substantial number of patients with megaloblastic or transitional erythropoiesis excrete normal quantities of Figlu in the urine. This confirms the finding of Chanarin et al (1963), who have shown that the absorption and excretion of histidine are altered in pregnancy, but is in marked contrast to that of Hibbard and Hibbard (1963), who considered that normal Figlu excretion excludes the possibility of megaloblastic erythropoiesis in pregnancy.

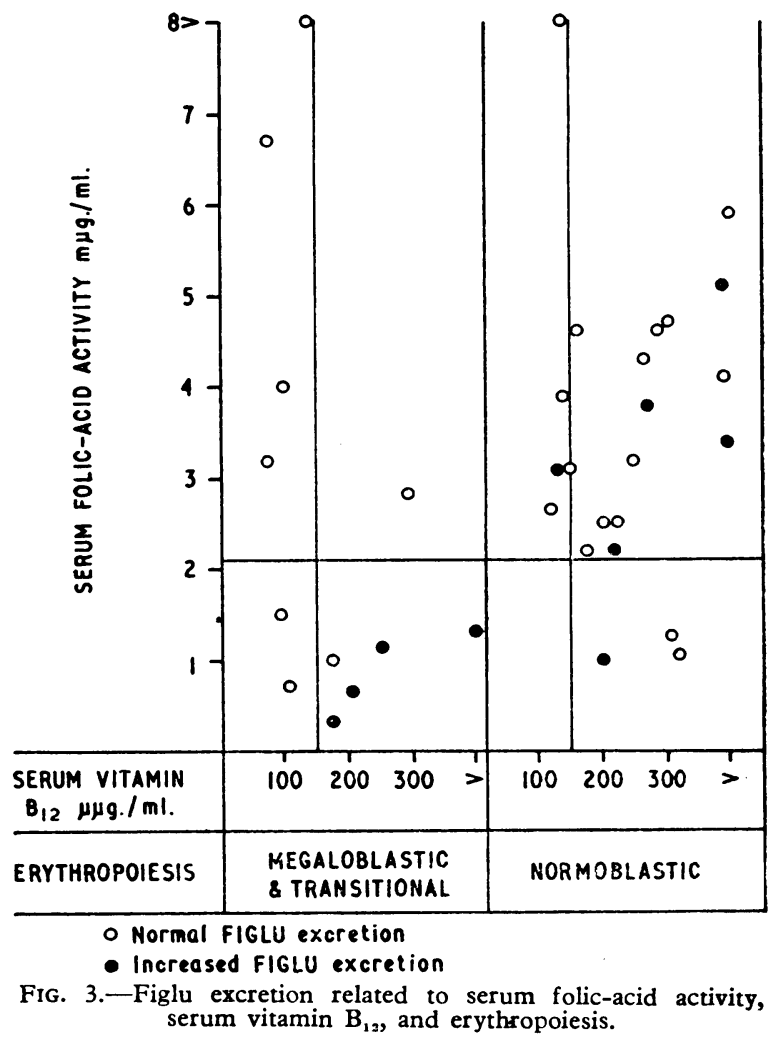

Although the measurement of the serum F.A.A. was not diagnostic it was found to be a better guide to the type of erythropoiesis than the Figlu excretion. In some patients with anaemia and transitional or megaloblastic erythropoiesis the Figlu excretion was increased and the serum F.A.A. was low, as one would expect if the anaemia were due to folic-acid deficiency. An unexpected finding was that a significant number of patients with normal Figlu excretion had low serum vitamin- $B_{12}$ levels when compared with those in whom the Figlu excretion was increased (Table IV). This was most striking in patients who had a transitional or megaloblastic bone-marrow, but a similar tendency was found in those with normoblastic erythropoiesis. Unfortunately, both serum F.A.A. and serum vitamin- $B_{12}$ levels were available on onl a limited number of patients, but Fig. 3 shows that patients with a megaloblastic or transitional marrow who had normal Figlu excretion usually had either a low serum vitamin $B_{13}$ alnne. or a low serum vitamin $B_{12}$ and a low serum F.A.A.

The association of low serum vitamin- $B_{12}$ levels and anaemia in pregnancy is being recognized more frequently as more pregnant women have their serum vitamin- $B_{12}$ levels estimated (Ball and Giles, 1964). All five cases described by Ball and Giles with megaloblastic erythropoiesis and subnormal vitamin$\mathrm{B}_{12}$ levels responded to folic acid. This suggests that a true vitamin- $B_{12}$ deficiency was not present and that the folic-acid deficiency had caused the serum vitamin- $B_{12}$ level to become subnormal. In our series there were four patients with transitional or megaloblastic erythropoiesis and normal Figlu excretion in whom the serum vitamin $B_{12}$ was low and serum F.A.A. 
was normal. One of these was treated with folic acid $5 \mathrm{mg}$. t.d.s., but there was no haematological improvement after four weeks of therapy. Injections of vitamin $B_{12}$ were then given with good results. Malabsorption of vitamin $B_{12}$ can probably be excluded as the cause of the deficiency in this patient, as absorption of radioactive vitamin $B_{12}$ was normal several months after delivery.

The cause of the low serum vitamin- $B_{12}$ levels found in pregnancy is obscure. A progressive decrease in the serum vitamin- $B_{12}$ levels of normal women as pregnancy progressed was found by Lowenstein et al. (1962), but the total circulating serum vitamin $B_{12}$ did not change significantly $A$ low serum vitamin $B_{12}$ was associated with megaloblastic erythropoiesis in a high proportion of their cases, however, and they felt that this probably indicated true vitamin deficiency. Vitamin- $B_{12}$ absorption has been shown to be normal in megaloblastic anaemia in pregnancy by Badenoch et al. (1955). It is therefore unlikely that these low levels are due to poor absorption, but rather are the result of excessive utilization by the foetus or are secondary to a deficiency of folic acid. This may not be true in every case, however, as one patient with low serum vitamin $B_{12}$ investigated before this study started has since been shown to have a true absence of intrinsic factor in spite of her haemoglobin returning to normal after delivery.

There is evidence to suggest that folic-acid deficiency may exist during pregnancy without megaloblastic erythropoiesis developing (Chanarin et al., 1959), in which case it is likely that anaemia due to folic-acid deficiency may be commoner than is at present thought. If this is so it would be of interest to know whether increased Figlu excretion gives an indication of such deficiency. Our own data suggest that this is unlikely, as there is no correlation between Figlu excretion and serum F.A.A. in patients with a normoblastic bone-marrow (Fig. 1). Furthermore, 3 of the 20 patients with a normal haemoglobin concentration had increased Figlu excretion, a proportion similar to that found by Berry et al. (1963), who did serial estimations of urinary Figlu in a group of normal pregnant women. It is clearly important to determine whether a normoblastic anaemia which responds to treatment with folic acid does occur in pregnancy. We believe that this point can be settled only by means of a controlled therapeutic trial, and such a trial is in progress.

\section{Summary}

In the present study the urinary excretion of Figlu has been estimated in 102 pregnant women and correlated with the haematological state, including the bone-marrow appearance in every case and the serum folic-acid activity and serum vitamin$B_{12}$ levels where available. Estimation of Figlu excretion was of little value in the diagnosis of the type of anaemia and was no substitute for bone-marrow biopsy; the serum folic-acid activity was found to be a better guide to the type of erythropoiesis. A number of patients were found to have low serum vitamin- $B_{12}$ levels in association with normal Figlu excretion and a significant proportion of these had megaloblastic or transitional erythropoiesis.

We are grateful to Professor L. J. Witts for helpful criticism and advice and for allowing us to use the facilities in his department for the folic-acid assays, which were carried out under the direction of Dr. G. H. Spray ; to Professor Chassar Moir and Mr. Mosteyn Embrey, who kindly allowed us to study patients under their care; and to Dr. R. Wright for all his help. This study has been financed by a grant from the Nuffield Committee for Advancement in Medicine.

\section{REFERENCES}

Badenoch, J., Callender, S. T., Evans, J. R., Turnbull, A. L., and Witts, L. J. (1955). Brit. med. भ̆., 1, 1245.

Ball, E. W., and Giles, C. (1964). \%. clin. Path., 17, 165

Berry, V., Booth, M A., Chanarin, I., and Rothman, D. (1963). Brit. med.' F., 2, 1103 .

Boczarow, B. (1961). f. clin. Path., 14, 189.

Chanarin, I., MacGibbon, B. M., O'Sullivan, W. J., and Mollin, D. L. (1959). Lancet, 2, 634.

- Rothman, D., and Watson-Williams, E. J. (1963). Ibid., 1, 1068.

Fisher, M., and Biggs, R. (1955). Brit. med. F., 1, 385.

Fisher, M., and Biggs, R. (1955). Brit. med. H., 1, and Hibbard, E. D. (1963). Ibid., 2, 1430.

Hibbard, E. D. (1962). F. Obstet. Gynaec. Brit. Cwlth, 69, 739.

Knowles, J. P., Prankerd, T. A. J., and Westall, R. G. (1960). Lancet, 2, 347 .

Kohn, J., Mollin, D. L., and Rosenbach, L. M. (1961). ¥. clin. Path., 14, 345 .

Lawrence, A. C. K. (1962). 7. Obstet. Gynaec. Brit. Cwlth, 69, 29.

Lowenstein, L., Hsieh, Y.-S., Brunton, L., De Leeuw, N. K. M., and Cooper, B. A. (1962). In Proceedings of 8th Congress of European Society of Haematology, Vienna, 1961, Part II, p. 337. Karger,

Luhby, A. L., Cooperman, J. M., and Teller, D. N. (1959). Proc. Soc. $\exp$. Biol. (N.Y.), 101, 350

Spray, G. H. (1964). F. clin. Path., 17, 660

Waters, A. H., and Mollin, D. L. (1961). Ibid., 14, 335.

\title{
Nephritis and Common Skin Diseases
}

\author{
R. SUMMERLY,* M.B., CH.B., M.R.C.P., M.R.C.P.ED. ; P. W. MONCKTON COPEMAN,* M.B., M.R.C.P.
}

Brit. med. F., 1964, 2, 1369-1371

Glomerulonephritis may accompany some common dermatoses, especially those in which haemolytic streptococci play a part. In anaphylactoid purpura renal involvement is well documented, but in erythema multiforme, erythema nodosum, acute guttate psoriasis, and those pyodermas which harbour streptococci the occurrence of glomerulonephritis is less well appreciated.

The following case histories show how glomerulonephritis may accompany apparently benign skin diseases.

\section{Case Histories}

\section{Case 1. Acute Nephritis ; Insect Bites ; Erythema Multiforme}

A woman aged 51 had had an itchy eruption on the shins, thighs, buttocks, and forearms, with malaise and pains in the elbows, knees, and ankles for two weeks. There was no history of recent sore throat, herpes simplex infections, or drug ingestion. She was a chronic alcoholic. In 1957 she had been treated for syphilis and gonorrhoea, and in 1962 for body lice; in early 1963 she had had an urticarial reaction after eating crab, and at the end of 1963 had eaten fish roes a few days before the symptoms which led to her admission to hospital. The skin on the ankles, calves, and buttocks had a number of erythematous papules $0.5-1 \mathrm{~cm}$. in diameter with central haemorrhagic puncta. Some were arranged in lines and were bed-bug bites. She also had lesions of erythema multiforme on the legs and forearms; some were bullous (1-2 cm. diameter) and others target-like. Pubic lice were present. The joints of the ankles, knees, and elbows were painful and at times swollen. The liver was palpable, the blood-pressure 120/70, and the urinalysis normal.

Investigations.-Four days after admission the blood-pressure had risen to $175 / 115$, reaching a maximum on daily testing of $180 / 120$,

* Skin Department, St. Thomas's Hospital, London. 